\title{
SISTEM PEMIDANAAN BAGI ANAK PENGEDAR NARKOTIKA DENGAN HUKUMAN PELATIHAN
}

\author{
Mhd. Teguh Syuhada Lubis \\ Fakultas Hukum Universitas Muhammadiyah Sumatera Utara \\ Jl. Kapt. Mukhtar Basri Nomor 3, Medan - Sumatera Utara \\ Email: $\underline{\text { mhdteguhsyuhada@umsu.ac.id }}$
}

\begin{abstract}
Abstrak
Anak yang berhadapan dengan hukum dan Anak yang berkonflik dengan hukum semakin banyak terungkap. Media massa melaporkan telah terjadi berbagai kasus yang melibatkan Anak, baik sebagai pelaku, korban, atau sebagai saksi. Masalah Anak ini merupakan bagian dari kerawanan sosial yang sering dikaji dan kemudian menjadi dokumen yang berisi rekomendasi bagi pemerintah sebagai pemangku kepentingan yang utama. Namun kerawanan itu tetap biasa atau bertambah, seolah-olah tidak ada yang mengatasinya. Metode pada penelitian ini adalah, Penelitian ini menggunakan pendekatan yuridis normatif. Penelitian hukum normatif disebut juga penelitian hukum doktrinal, dimana hukum dikonsepkan sebagai apa yang tertuliskan peraturan perundang-undangan (law in books), dan penelitian terhadap sistematika hukum dapat dilakukan pada peraturan perundang-undangan tertentu atau hukum tertulis, sehingga permasalahan yang diangkat dalam penelitian ini adalah terkait dengan bagaimana sistem pemidanaan sebagai hukuman pelatihan bagi Anak pengedar narkotika?. .sehingga yang menjadi hasil penelitian ini adalah Faktor dalam pelaksanaan hukuman pelatihan sebagai sistem pemidanaan bagi anak pengedar narkotika yaitu faktor intelegensia, faktor usia, faktor kedudukan anak dalam keluarga, faktor pendidikan dan sekolah, Serta dalam undang-undang narkotika itu tidak membedakan secara khusus antara pelaku tindak pidana narkotika, baik pelaku yang menyuruh lakukan, yang turut serta melakukan dan penganjur maupun pembantu dapat disebut sebagai pelaku tindak pidana. Keterlibatan anak dalam tindak pidana narkotika yang menjadi kurir narkotika merupakan suatu rangkaian permufaktan jahat dalam menjalankan peredaran narkotika secara ilegal, tetapi dalam kapasitas kategori anak yang menjadi kurir, Tindakan hukum yang diberlakukan terhadap mereka harus lebih mengedepankan pembinaan dan pemulihan hak-hak mereka, tanpa harus dikenai tindakan hukum yang berlebihan. Akan menjadi persoalan yang rumit dari sisi keadilan apabila konflik hukum terjadi bukan sekedar antara anak dengan negara atau masyarakat, akan tetapi konflik hukum itu terjadi juga dalam relasi antaranak yang sama-sama mempunyai hak mendapat perlindungan
\end{abstract}

Kata Kunci: Pemidanaan, Anak, Narkotika, Hukuman Pelatihan.

\section{PENDAHULUAN}

Secara sederhana, pelatihan adalah proses pendidikan jangka pendek yang menggunakan prosedur yang sistematis dan terorganisir. Anak sebagai salah satu sumber daya manusia dan merupakan generasi penerus bangsa, sudah selayaknya mendapatkan perhatian khusus dari pemerintah, dalam rangka pembinaan anak untuk mewujudkan sumber daya manusia yang tangguh serta berkualitas. Berkaitan dengan pembinaan anak diperlukan sarana dan prasarana hukum guna mengantisipasi segala permasalahan yang timbul. Sarana dan prasarana yang dimaksud menyangkut kepentingan anak maupun yang menyangkut penyimpangan sikap dan perilaku yang menjadikan anak terpaksa dihadapkan ke muka pengadilan.

Anak yang berhadapan dengan hukum dan anak yang berkonflik dengan hukum semakin banyak terungkap. Media massa melaporkan telah terjadi berbagai kasus yang melibatkan anak, baik sebagai pelaku, korban, atau sebagai saksi. Masalah anak ini merupakan bagian dari kerawanan sosial yang sering dikaji dan kemudian menjadi dokumen yang berisi rekomendasi bagi pemerintah sebagai pemangku kepentingan yang utama. Namun kerawanan itu tetap biasa atau bertambah, seolah-olah tidak ada yang mengatasinya.

Jumlah kasus anak yang berhadapan dengan hukum terus meningkat. Komisi Perlindungan Anak Indonesia (KPAI) melaporkan, terjadi peningkatan jumlah kasus kekerasan maupun kasus penyalahgunaan narkoba oleh anak. Dilaporkan, pada 2011 terjadi 2. 178 kasus, 2012 terjadi 3.512 kasus, 2013 terjadi 4.011 kasus, dan 2014 terjadi 5.066 kasus. Kondisi ini merupakan potret buram masyarakat Indonesia yang terbelenggu oleh kerawanan sosial. Pengelolaan masalah anak yang berkonflik dengan hukum belum memberikan hasil yang baik.

Penyalahgunaan narkotika tak lagi memandang usia, mulai dari anak-anak, remaja, orang dewasa hingga orang tua sekalipun tak luput dari jeratan penyalahgunaan narkotika ini. Diperkirakan sekitar 1,5 persen dari total penduduk Indonesia adalah korban dari penyalahgunaan narkotika tersebut. Masalah 
peredaran narkotika ini juga tak kalah mengkhawatirkan, karena tidak hanya terjadi di kota-kota besar saja juga merambah ke pelosok Indonesia. Sehubungan dengan populasi penduduk yang sangat besar, melebihi angka 200.000.000 (dua ratus juta) jiwa, maka Indonesia merupakan pasar potensial bagi peredaran gelap narkotika. Pada awalnya Indonesia hanya sebagai tempat persinggahan lalu lintas perdagangan narkotika, dikarenakan lokasinya yang strategis. Lambat laun para pengedar gelap narkotika ini mulai menjadikan Indonesia sebagai pasar incaran untuk mengedarkan narkotika. Seiring berjalanannya waktu Indonesia mulai bertransformasi, tidak hanya sebagai tempat peredaran narkotika namun juga sudah menjadi tempat menghasilkan narkotika. Hal ini terbukti dengan ditemukannya beberapa laboratorium narkotika di wilayah Indonesia.

Narkotika adalah zat atau obat yang berasal dari tanaman atau bukan tanaman, baik sintetis maupun semisintetis yang dapat menyebabkan penurunan atau perubahan kesadaran, hilangnya rasa nyeri, dan dapat menimbulkan ketergantungan. Undang-Undang Nomor 35 Tahun 2009 tentang Narkotika yang telah mengatur tentang ketentuan pidana bagi siapa saja yang dapat dikenakan pidana beserta denda yang harus ditanggung oleh penyalahgunaan narkotika atau dapat disebut sebagai pelaku narkotika.

Undang-Undang Republik Indonesia Nomor 35 Tahun 2009 Pasal 113 ayat (1) tentang Narkotika disebutkan bahwa mengimpor, mengekspor, memproduksi, menanam, menyimpan, mengedarkan, dan mengunakan narkotika tanpa pengendalian dan pengawasan yang ketat, serta bertentangan dengan peraturan perundang-undangan yang berlaku adalah kejahatan. Dalam undang-undang narkotika tersebut juga disebutkan bahwa narkotika merupakan suatu kejahatan karena sangat merugikan dan merupakan bahaya yang sangat besar bagi manusia, masyarakat, bangsa, dan Negara serta ketahanan nasional Indonesia.

Untuk mengelabui pihak berwajib, tidak jarang para pengedar narkotika memanfaatkan anak di bawah umur untuk dijadikan kurir obatobatan terlarang tersebut. Kurangnya pengetahuan terhadap narkotika, dan ketidakmampuan untuk menolak serta melawan membuat anak di bawah umur menjadi sasaran bandar narkotika untuk mengedarkan narkotika secara luas dan terselubung. Persoalan ini tentu menjadi masalah yang sangat serius, karena dapat menjerumuskan anak dibawah umur dalam bisnis gelap narkotika.

Undang-Undang Narkotika itu tidak membedakan secara khusus antara pelaku tindak pidana narkotika, baik pelaku yang menyuruh lakukan, yang turut serta melakukan dan penganjur maupun pembantu dapat disebut sebagai pelaku tindak pidana. Keterlibatan anak dalam tindak pidana narkotika yang menjadi kurir narkotika merupakan suatu rangkaian permufakatan jahat dalam menjalankan peredaran narkotika secara ilegal, tetapi dalam kapasitas kategori anak yang menjadi kurir. Hal ini merupakan satu hal yang begitu memprihatinkan, di mana anak tersebut telah berhadapan dengan hukum dan tergolong telah melakukan tindak pidana narkotika.

Peran keluarga anak sangatlah penting untuk mencegah terjadinya seseorang memperalat anak tersebut untuk mengedarkan narkotika. Anak adalah bagian dari generasi muda yang merupakan potensi dan penerus citacita perjuangan bangsa di masa yang akan datang. Anak membutuhkan pembinaan dan perlindungan khusus dalam menjamin pertumbuhan dan perkembangan fisik, mental dan sosial secara seimbang. Sungguh ironis bahwa seorang Anak yang seharusnya bermain dan belajar harus menghadapi masalah hukum dan menjalani proses peradilan yang hampir sama prosesnya dengan orang dewasa. Tentu saja hal ini menimbulkan pro kontra. Di satu sisi banyak pihak yang menganggap menjatuhkan pidana bagi anak adalah tidak bijak, namun ada sebagian yang beranggapan pemidanaan terhadap anak penting dilakukan agar sikap buruk anak tidak terjadi sampai dewasa, artinya agar memberi efek jera bagi anak. ${ }^{1}$

Anak sebagai pelaku tindak pidana harus diperlakukan secara manusiawi untuk kepentingan terbaik bagi anak untuk mewujudkan pertumbuhan dan memberikan perkembangan fisik, mental dan sosial. Negara dan Undang-Undang wajib memberikan perlindungan hukum yang berlandaskan hak-hak anak, sehingga diperlukan pemidanaan edukatif terhadap Anak. Permasalahan yang dikemukakan ini adalah bagaimana aturan sistem pemidanaan sebelum pengaturan Restorative Justice di Indonesia dan bagaimana sistem pemidanaan edukatif setelah pengaturan Restorative Justice yang tepat ke depannya. ${ }^{2}$

Sistem peradilan Anak wajib mengutamakan pendekatan keadilan Restoratif sistem peradilan anak dimaksud meliputi:

${ }^{1}$ Serambinews.com, "memahamiana" http://aceh.tribunnews.com/2017/01/26/memaha mi-nak-yang-berkonflik-hukum , diakses 2 januari 2019, pukul 09.00 WIB.

${ }^{2}$ Nursariani Simatupang dan Faisal.2018. Hukum Perlindungan Anak. CV. Pustaka Prima, Medan, halaman 166. 
a. Penyidikan dan penuntutan pidana Anak yang dilaksanakan sesuai dengan ketentuan peraturan perundang-undangan kecuali ditentukan lain dalam undangundang ini;

b. Persidangan anak yang dilakukan oleh pengadilan di lingkungan peradilan umum; dan pembinaan, pembimbingan, pengawasan dan/atau pendampingan selama proses pelaksanaan pidana atau tindakan dan setelah menjalani pidana atau tindakan.

Pada hakekatnya, segala bentuk penanganan terhadap anak yang menghadapi masalah hukum dalam hal ini menghadapai masalah mengedarkan narkotika harus dilakukan dengan memprioritaskan kepentingan terbaik untuk si anak. Oleh karena itu keputusan yang diambil dalam kasus tersebut harus adil dan proposional tidak semata-mata dilakukan atas pertimbangan hukum tapi juga mempertimbangkan faktor lain seperti kondisi lingkungan sekitar, status sosial anak, dan keadaan keluarga. Jadi, perlakuan hukum pada anak di bawah umur pada kasus perdagangan narkotika sudah selayaknya mendapatkan perhatian yang serius.

Kemampuan anak yang masih terbatas dan tidak sesempurna orang dewasa harus diperhatikan oleh aparat penegak hukum dalam menerapkan pemidanaan bagi anak pelaku tindak pidana narkotika. Dikeluarkannya UndangUndang Nomor 11 Tahun 2012 tentang sistem peradilan pidana anak sebagaimana pengganti dari Undang-Undang Nomor 3 Tahun 1997 tentang pengadilan anak akan memberikan penerapan pemidanaan yang lebih bersifat membina dan melindungi terhadap anak pelaku tindak pidana. Pertanggung jawaban pidana anak sebagai kurir narkotika adalah kewajiban untuk menanggung suatu perbuatan yang melanggar tindak pidana yang dilakukan oleh anak sebagai seseorang yang diutus untuk menyampaikan narkotika.

Penegak hukum dalam memproses dan memutuskan harus yakin benar bahwa keputusan yang diambil akan menjadi satu dasar yang kuat untuk mengembalikan dan mengatur anak menuju masa depan yang baik untuk mengembangkan dirinya sebagai warga masyarakat yang bertanggungjawab bagi kehidupan bangsa. Sistem Pemidanaan itu sendiri berorientasi kepada individu pelaku atau biasa disebut pertanggungjawaban individual atau personal (individual responbility) dimana pelaku dipandang sebagai individu yang mampu untuk bertanggung jawab penuh terhadap perbuatan yang dilakukannya. Sedangkan Anak merupakan individu yang belum dapat menyadari secara penuh atas tindakan atau perbuatan yang diakukannya, hal ini disebabkan karena anak merupakan individu yang belum matang dalam berpikir. Oleh sebab itu dengan memperlakukan anak itu sama dengan orang dewasa maka dikhawatirkan si anak akan dengan cepat meniru perlakuan dari orang-orang dekatnya.

Anak yang berhadapan dengan hukum adalah anak yang berkonflik dengan hukum, Anak yang menjadi korban tindak pidana, anak yang menjadi saksi tindak pidana. Anak berhadapan dengan hukum selanjutnya disebut adalah anak yang telah berumur 12 (dua belas) Tahun, tetapi belum berumur 18 (delapan belas) tahun yang diduga melakukan tindak pidana. Anak yang menjadi korban tindak pidana yang disebut sebagai anak korban adalah anak yang belum berumur 18 (delapan belas) tahun yang mengalami penderitaan fisik, mental atau kerugian ekonomi yang disebabkan oleh tindak pidana. Anak yang menjadi saksi adalah belum berumur 18 (delapan belas) tahun yang dapat memberikan keterangan guna kepentingan penyidikan, penuntutan, dan pemeriksaan di sidang pengadilan tentang suatu perkara pidana yang didengar, dilihat dan atau dialaminya sendiri. Hakikatnya, ruang lingkup pengaturan anak, anak saksi dan anak korban dalam Sistem Peradilan Pidana Anak adalah keseluruhan proses penyelesaian perkara anak berhadapan dengan hukum, mulai tahap penyelidikan sampai dengan tahap pembimbingan setelah menjalani pidana.

Dimensi utama subtansial disahkannya Undang-Undang Sistem Peradilan Pidana Anak oleh pembentuk Undang-Undang adalah untuk menjaga harkat dan martabat anak, Anak berhak mendapat perlindungan khusus, terutama perlindungan hukum dalam sistem peradilan. Dengan demikian, diharapkan diharapkan kepada penegak hukum yang menangani perkara anak, mulai dari tingkat penyidikan sampai tingkat persidangan, untuk mendalami masalah anak. agar nantinya anak, setelah perkaranya diputus, anak tersebut baik secara fisik dan mental siap menghadapi masa depannya secara lebih baik.

Berdasarkan penjatuhan pidana subsider wajib latihan kerja oleh hakim hanya diberikan dalam hal anak dijatuhi pidana kumulatif penjara dan denda. Bila mana denda tidak dibayar maka anak wajib melaksanakan latihan kerja (Pasal 28 Undang-Undang Nomor 3 Tahun 1997 tentang Pengadilan Anak Jo Pasal 71 ayat (3) Undang-Undang Nomor 11 Tahun 2012 Tentang Sistem Peradilan Pidana Anak) paling lama 90 (sembilan puluh) hari dan lama latihan kerja tidak lebih dari 4 (empat) jam sehari serta tidak dilakukan pada malam hari, dimana bertujuan untuk memberikan keterampilan kepada anak sebagai bekal untuk kembali pada masyarakat. 
Konsep pidana subsider wajib latihan kerja ditujukan untuk menciptakan anak yang berasal dari keluarga tidak mampu dapat mandiri sebagai seorang yang profesional dibidangnya. Oleh karena itu, masalah dalam tulisan ini untuk mengukur apakah pelaksanaan pidana subsider latihan kerja sudah efektif atau tidak. Hasil penelitian menunjukan pelaksanaan pidana subsider wajib latihan kerja sepenuhnya menjadi tanggungjawab pihak swasta tanpa adanya program latihan kerja dan tidak adanya pengawasan intensif oleh Dinas Sosial.

Menurut Pasal 64 ayat (2) huruf b dimaksud dalam Pasal 59 Undang-Undang Nomor 35 Tahun 2014 Perlindungan Khusus Bagi Anak Yang Berhadapan dengan hukum dilakukan melalui:

a. Perlakuan secara manusiawi dengan memperhatikan kebutuhan sesuai dengan umurnya;

b. Pemisahan dari orang dewasa;

c. Pemberian bantuan hukum dan bantuan lain secara efektif;

d. Pemberlakuan kegiatan rekresional;

e. Pembebasan dari penyiksaan, penghukuman, atau perlakuan lain yang kejam, tidak manusiawi serta merendahkan martabat dan derajatnya;

f. Penghindaran dari penjatuhan pidana mati dan/ atau pidana seumur hidup;

g. Penghindaran dari penangkapan, penahanan atau penjara, kecuali sebagai upaya terakhir dan dalam waktu yang paling singkat;

h. Pemberian keadilan dimuka pengadilan anak yang objektif, tidak memihak, dan dalam sidang yang tertutup untuk umum;

i. Penghindaran dari publikasi atas identitasnya;

j. Pemberian pendampingan orang tua/wali dan orang yang dipercaya oleh anak;

Ancaman pidana penjara yang dapat dijatuhkan kepada Anak paling lama 1/2 (satu perdua) dari maksimum ancaman pidana penjara bagi orang dewasa. Artinya, ancaman pidana bagi anak yang menjadi kurir narkotika adalah setengah dari ancaman pidana yang terdapat dalam Undang-Undang Narkotika.Terhadap anak-anak yang menjadi kurir atau perantara narkotika, harus didasarkan pada mekanisme yang diatur dalam Undang-Undang Perlindungan anak dan Undang-Undang Sistem Peradilan Anak. Penegakan hukum bagi pelaku yang masih berusia di bawah, terdapat ketentuan khusus yang dinamakan dengan diversi, yakni pengalihan penyelesaian perkara Anak dari proses peradilan pidana ke proses di luar peradilan pidana.
Berdasarkan Undang-Undang Nomor 23 tahun 2002 tentang perlindungan Anak sebagaimana diubah oleh Undang-Undang Nomor 35 tahun 2014 tentang perubahan atas Undang-Undang Nomor 23 tahun 2002 tentang perlindungan Anak pada tingkat penyidikan, penuntutan, dan pemeriksaan perkara Anak di pengadilan negeri wajib diupayakan diversi. Namun diversi hanya dapat dilakukan dengan syarat yakni dalam hal tindak pidana yang dilakukan diancam dengan pidana penjara di bawah 7 (tujuh) tahun dan perbuatan yang dilakukan si anak bukan merupakan pengulangan tindak pidana.

Sistem peradilan pidana anak upaya diversi dilakukan untuk menghindari dan menjauhkan anak dari proses peradilan sehingga dapat menghindari stigmatisasi terhadap anak yang berhadapan dengan hukum dan diharapkan anak dapat kembali ke dalam lingkungan sosial secara wajar. Proses diversi dilakukan dengan melalui musyawarah yang melibatkan anak dan orang tua/walinya, pembimbing kemasyarakatan, dan pekerja sosial profesional, yang dilakukan dengan pendekatan keadilan restoratif. ${ }^{3}$ Berdasarkan latar belakang yang diuraikan di atas, maka rumusan masalah yang diajukan dalam penulisan skripsi ini adalah bagaimana sistem pemidanaan sebagai hukuman pelatihan bagi Anak pengedar narkotika?

\section{METODE PENELITIAN}

Metode penelitian merupakan peranan penting dalam suatu faktor permasalahan untuk mendapatkan data dalam memecahkan masalah, dalam hal ini penelitian merupakan suatusarana untuk mengembangkan ilmu pengetahuan baik dari segi teoritis maupun praktis. Penelitian merupakan suatu bagian pokok dari ilmu pengetahuan, yang bertujuan untuk lebih mengetahui dan lebih memperdalami segala segi kehidupan. ${ }^{4}$

Penelitian ini menggunakan pendekatan yuridis normatif. Penelitian hukum normatif disebut juga penelitian hukum doktrinal, dimana hukum dikonsepkan sebagai apa yang tertuliskan peraturan perundang-undangan (law in books), dan penelitian terhadap sistematika hukum dapat dilakukan pada peraturan perundang-undangan

${ }^{3}$ Defenisipelatihan,https://www.google.c o.id/search?safe=strict\&ei=gh9bXPS1O8XkvgS NOZyICw\&q=hukuman+pelatihan+bagi+anak\& oq=hukuman+pelatihan+bagi+anak\&gs_l=psy-, diakses 7 february 2019 pukul 22.00 Wib.

${ }^{4}$ Soerjono Soekamto. 2014. Pengantar Penelitian Hukum. Jakarta: UI-PRESS, halaman 3. 
tertentu atau hukum tertulis. ${ }^{5}$ Penelitian ini bersifat deskriptif yaitu metode pengumpulan fakta ditujukan untuk mempelajari permasalahan yang timbul di masyarakat serta proses yang tengah berlangsung dalam masyarakat. Peneltian ini merupakan penelitian hukum yuridis normatif. Sehingga yang menjadi suber data dalam penelitian ini terdiri dari, data yang bersumber dari hukum islam yaitu Al-qur'an dan hadist(Sunnah Rasul), data sekunder yaitu data pustaka yang mencakup dokumen yang terdiri dari tiga bahan hokum, bahan hukum primer yaitu berupa peraturan perundang-undangan, Undang-Undang Nomor 35 Tahun 2014 Tentang Perlindungan Anak, Undang-Undang Nomor 11 Tahun 2012 Tentang Sistem Peradilan Pidana Anak, Undang-Undang Nomor 35 Tahun 2009 Tentang Narkotika, bahan hukum sekunder yaitu terdiri atas buku-buku, karya ilmiah, jurnal ilmiah, bahan hukum tersier yaitu penjelasan terhadap bahan hukum primer dan sekunder terdiri dari kamus hukum,Internet dan sebagainya.

\section{HASIL PENELITIAN PEMBAHASAN}

Anak yang melakukan tindak pidana dapat dikenakan sanksi pidana pidana, yaitu berupa pidana pokok dan pidana tambahan. Pidana pokok bagi anak ditentukan dalam Pasal 71 Undang-Undang Sistem Peradilan Pidana Anak. Adapun pidana pokok yang dapat dijatuhkan kepada Anak adalah:

a. Pidana peringatan
b. Pidana dengan syarat:

1) Pembinaan di luar lembaga;

2) Pelayanan masyarakat; atau

3) Pengawasan

c. Pelatihan kerja;

d. Pembinaan dalam lembaga; dan

e. Penjara.

Pidana tambahan yang dapat diberikan kepada Anak terdiri atas:

a. Perampasan keuntungan yang diperoleh dari tindak pidana; atau

b. Pemenuhan kewajiban adat.

Apabila dalam hukum materiil diancam pidana kumulatif berupa penjara dan denda, pidana denda diganti dengan pelatihan kerja. Pidana yang dijatuhkan kepada Anak dilarang melanggar harkat dan maartabat Anak. Ketentuan lebih lanjut mengenai bentuk dan tata cara pelaksanaan pidana bagi Anak selanjutnya diatur dengan peraturan pemerintah. Pidana

${ }^{5}$ Fakultas hukum Universitas Muhammadiyah Sumatera Utara, Dkk, Op Cit, halaman 19. peringatan merupakan pidana ringan yang tidak mengakibatkan pembatasan kebebasan Anak.

Pidana dengan syarat dapat dijatuhkan oleh hakim dalam hal pidana penjara yang dijatuhkan paling lama 2 (dua) tahun. Dalam putusan pengadilan mengenai pidana dengan syarat ditentukan syarat umum dan syarat khusus.

1. Syarat umum adalah anak tidak akan melakukan tindak pidana lagi selama menjalani masa pidana dengan syarat.

2. Syarat khusus adalah untuk melakukan atau tidak melakukan hal tertentu yang ditetapkan dalam putusan hakim dengan tetap memperhatikan kebebasan anak.

Masa pidana dengan syarat khusus lebih lama daripada masa pidana dengan syarat umum, jangka waktu masa pidana dengan syarat adalah paling lama 3 (tiga) tahun. Selama menjalani masa pidana dengan syarat, penuntut umum melakukan pengawasan dan pembimbing kemasyarakatan melakukan pembimbingan agar Anak menempati persyaratan yang telah ditetapkan.

Selama Anak menjalani pidana dengan syarat, Anak harus mengikuti wajib belajar 9 (sembilan) tahun. Dalam hal hakim memutuskan bahwa anak dibina di luar lembaga, maka lembaga tempat pendidikan dan pembinaan ditentukan dalam putusan hakim. Pidana pembinaan di luar lembaga yang dijatuhkan kepada anak dapat berupa keharusan:

a. Mengikuti program pembimbingan dan penyuluhan yang dilakukan oleh pejabat pembina;

b. Mengikuti terapi di rumah sakit jiwa; atau

c. Mengikuti terapi akibat penyalahgunaan alkohol, narkotika, psikotropika, dan zat adiktif lainnya.

Jika selama pembinaan Anak melanggar syarat khusus yang telah ditentukan, maka pejabat pembina dapat mengusulkan kepada hakim pengawas untuk memperpanjang masa pembinaan yang lamanya tidak melampaui maksimum 2 (dua) kali masa pembinaan yang belum dilaksanakan.Pidana pelayanan masyarakat merupakan pidana yang dimaksudkan untuk mendidik Anak dengan meningkatkan kepeduliannya pada kegiatan masyarakat yang positif. Jika anak tidak memenuhi seluruh atau sebagian kewajiban dalam menjalankan pidana pelayanan masyarakat tanpa alasan yang sah, pejabat pembina dapat mengusulkan kepada hakim pengawas untuk memerintahkan anak tersebut mengulangi seluruh atau sebagian pidana pelayanan masyarakat yang dikenakan terhadapnya. 
Pidana pelayanan masyarakat untuk anak dijatuhkan paling singkat 7 (tujuh) jam dan paling lama 120 (seratus dua puluh) jam. Pidana pengawasan yang dapat dijatuhkan kepada anak minimal 3 (tiga) bulan dan maksimal 2 (dua) tahun. Dalam hal anak dijatuhi pidana pengawasan, Anak akan ditempatkan di bawah pengawasan penutut umum dan dibimbing oleh pembimbing kemasyarakatan.

Seperti pada Pasal 78 Undang-Undang

Sistem Peradilan Pidana Anak, sebagai berikut:

1) Pidana pelatihan kerja sebagaimana dimaksud dalam pasal 71 ayat (1) huruf c dilaksanakan di lembaga yang melaksanakan pelatihan kerja yang sesuai dengan usia anak

2) Pidana pelatihan kerja sebagaimana dimaksud pada ayat (1) dikenakan paling singkat 3 (tiga) bulan dan paling lama 1 (satu) tahun.

Pidana pembatasan kebebasan diberlakukan dalam hal anak melakukan tindak pidana berat atau tindak pidana yang disertai dengan kekerasan. Pidana pembatasan kebebasan yang dijatuhkan terhadap anak paling lama $1 / 2$ (satu perdua) dari maksimum pidana penjara yang diancamkan terhadap orang dewasa. Minimum khusus pidana penjara tidak berlaku terhadap anak. Ketentuan mengenai pidana penjara dalam Kitab Undang-Undang Hukum Pidana(KUHP) berlaku juga terhadap anak sepanjang tidak bertentangan dengan UndangUndang Sistem Peradilan Pidana Anak. Pidana pembinaan di dalam lembaga dilakukan di tempat pelatihan kerja atau lembaga pembinaan yang diselenggarakan, baik oleh pemerintah maupun swasta.

Pidana pembinaan di dalam lembaga dijatuhkan apabila keadaan dan perbuatan anak tidak membahayakan masyarakat. Pembinaan dalam lembaga dilaksanakan paling singkat 3 (tiga) bulan dan paling lama 24 (dua puluh empat) bulan. Anak yang menjalani $1 / 2$ (satu perdua) dari lamanya pembinaan di dalam lembaga dan tidak kurang dari 3 (tiga) bulan berkelakuan baik berhak mendapatkan pembebasan bersyarat.

Anak dijatuhi pidana penjara di Lembaga Pembinaan Khusus Anak apabila keadaan dan perbuatan anak akan membahayakan masyarakat. Pidana penjara yang dapat dijatuhkan kepada anak paling lama $1 / 2$ (satu perdua) dari maksimum ancaman pidana penjara bagi orang dewasa. pembinaan di Lembaga Pembinaan Khusus Anak dilaksanakan sampai anak berumur 18 (delapan belas) tahun. Anak yang telah menjalani $1 / 2$ (satu perdua) dari lamanya pembinaan dan berkelakuan baik berhak mendapatkan pembebasan bersyarat.
Pidana penjara terhadap anak hanya digunakan sebagai upaya terakhir. Jika tindak pidana yang dilakukan anak merupakan tindak pidana yang diancam dengan pidana mati atau pidana penjara seumur hidup, pidana yang dijatuhkan adalah pidana penjara paling lama 10 (sepuluh) tahun. Anak yang melakukan tindak pidana selain dapat dikenakan sanksi pidana juga dapat dikenakan tindakan.

Pasal 21 Undang-Undang Sistem Peradilan Pidana Anak menyatakan bahwa dalam hal Anak belum berumur 12 (dua belas) tahun melakukan atau diduga melakukan tindak pidana, penyidik, pembimbing kemasyarakatan, dan pekerja sosial profesional mengambil keputusan untuk:

a. Menyerahkan kembali kepada orang tua/wali; atau

b. Mengikutsertakan dalam program pendidikan, pembinaan, dan pembimbingan di instansi pemerintah atau LPKS di instansi yang menangani bidang kesejahteraan sosial, baik di tingkat pusat maupun daerah, paling lama 6 (enam) bulan.

Pasal 69 Undang-Undang Nomor 11 Tahun 2102 Sistem Peradilan Pidana Anak menyatakan bahwa anak yang belum berusia 14 (empat belas) tahun hanya dapat dikenai tindakan. Pasal 82 Undang-Undang Sistem Peradilan Pidana Anak menyatakan bahwa tindakan yang dapat dikenakan kepada anak meliputi:

a. Pengembalian kepada orang tua/wali;

b. Penyerahan kepada seseorang;

c. Perawatan di rumah sakit jiwa;

d. Perawatan di LPKS;

e. Kewajiban mengikuti pendidikan formal dan/atau pelatihan yang diadakan oleh pemerintah atau badan swasta;

f. Pencabutan surat izin mengemudi; dan/atau

g. Perbaikan akibat tindak pidana.

Tindakan yang diberikan kepada anak karena telah melakukan tindak pidana dikenakan paling lama 1 (satu) tahun. Tindakan dapat dijatuhkan oleh penuntut umum dalam tuntutannya, kecuali tindak pidana diancam dengan pidana penjara paling singkat 7 (tujuh) tahun. Tindakan penyerahan anak kepada seseorang dilakukan untuk kepentingan anak yang bersangkutan. Tindakan perawatan terhadap anak dimaksudkan untuk membantu 
orang tua/wali dalam mendidik dan memberikan pembimbingan kepada anak yang bersangkutan. ${ }^{6}$

Menurut Pasal 60 ayat (1) UndangUndang Nomor 11 Tahun 2012 Lembaga Pembinaan Khusus Anak adalah tempat pembinaan dan pendidikan bagi anak pidana, Anak Negara dan Anak sipil. Penempatan ini dilakukan terpisah dari narapidana dewasa. Bagi anak yang ditempatkan di Lembaga Pembinaan Khusus Anak berhak untuk memperoleh pendidikan dan latihan, baik formal maupun informal sesuai bakat, dan kemampuannya serta memperoleh hak-hak lainnya.

Diversi merupakan hal yang wajib diupayakan pada setiap tingkat pemeriksaan, dan bahkan ketentuan Pasal 95 Undang-Undang Sistem Peradilan Pidana Anak memberikan ancaman sanksi administratif bagi pejabat atau petugas yang melanggar mengupayakan diversi sesuai dengan ketentuan peraturan perundangundangan. Dalam praktik peradilan, proses diversi apabila berhasil ditindaklanjuti dengan hasil kesepakatan diversi, kemudian semuanya dicatat pada Register kesepakatan diversi yang ada pada pengadilan Negeri setempat.

Pemilihan kebijakan pembentuk Undang-Undang yang menerapkan diversi menurut penulis sebenarnya menimbulkan adanya beberapa implikasi dan problematika. Pertama, berpotensi melanggar hak anak yang berhadapan dengan hukum karena pembentuk Undang-Undang Sistem Peradilan Pidana Anak tidak mengatur secara eksplisit klausula, Anak yang telah mengaku bersalah melakukan tindak pidana/kejahatan, sebagai salah satu syarat penentu atau pertimbangan untuk dilakukannya diversi. Kedua, kewajiban pelaksanaan diversi senyatanya melanggar hak Anak atas asas praduga tak bersalah (asas presumption of innouncence). Ketiga, kewajiban pelaksanaan diversi melanggar hak anak atas peradilan yang adil dan tidak memihak (fair trial). Keempat, diversi hanya dilaksanakan dalam hal tindak pidana yang diancam dengan pidana penjara di bawah 7(tujuh) tahun dan bukan merupakan pengulangan tindak pidana sebagaimana ditentukan Pasal 7 ayat (2) huruf a dan b Undang-Undang Sisitem Peradilan Pidana Anak.

Khusus konteks diversi yang dilaksanakan terhadap tindak pidana penjara di bawah 7(tujuh) tahun ternyata pembentuk Undang-Undang Sistem Peradilan Pidana Anak telah menimbulkan ambiguitas polarisasi pemikiran sehingga secara tidak langsung bersikap diskriminatif yaitu dengan cara menerapkan perlakuan berbeda dalam hal

${ }^{6}$ Nursariani Simatupang dan Faisal, Op.Cit., halaman 181. menangani Anak berhadapan dengan hukum. Konkretnya, di satu sisi diversi imperatif dilakukan khusus terhadap tindak pidana penjara di bawah 7(tujuh) tahun, di sisi lainnya tidak dilaksanakan dalam hal tindak pidana yang dilakukan diancam dengan pidana penjara 7 (tujuh) tahun atau lebih. Seharusnya, UndangUndang Sistem Peradilan Pidana Anak yang menganut filosofis untuk kepentingan terbaik bagi anak, maka seyogyanya diversi dilakukan untuk semua tindak pidana yang dilakukan oleh anak. tegasnya, diversi tidak hanya dilaksanakan dalam hal tindak pidana yang dilakukan diancam dengan pidana penjara di bawah 7 (tujuh) tahun.

Persoalan pelaku tindak pidana anak, bukan hanya persoalan di Indonesia saja tetapi, merupakan masalah dunia, terdapat perilaku anak yang dianggap menyimpang oleh masyarakat di sekitarnya. Sehubungan dengan hal itu United Nations Children fund (UNICEF) mengembangkan konsep Restoratif Justice untuk melindungi pelaku tindak pidana anak. konsep Restoratif Justice menitik beratkan kepada keadilan yang dapat memulihkan, yaitu memulihkan bagi pelaku tindak pidana Anak, korban dan masyarakat yang terganggu akibat adanya tindak pidana tersebut.

Proses pemulihan menurut konsep Restoratif Justice adalah melalui diversi, yaitu pengalihan atau pemindahan dari proses peradilan ke dalam proses alternatif penyelesaian perkara, yaitu melalui musyawarah pemulihan atau mediasi. Langkah pengalihan dibuat untuk menghindarkan anak dari tindakan hukum selanjutnya dan untuk dukungan komunitas, di samping itu pengalihan bertujuan untuk mencegah pengaruh negatif dari tindakan hukum berikutnya yang dapat menimbulkan stigmatisasi. Pengalihan dapat dilakukan atas dasar kewenangan diskresi dari penyidik atau penuntut umum atau hakim, sesuai dengan tingkat pemeriksaan melalui suatu penetapan. Apabila perkaranya tidak dapat diselesaikan secara mediasi Sistem Peradilan Pidana Anak harus mengacu pada due process of law, sehingga hak asasi Anak yang diduga melakukan tindak pidana dan/atau telah terbukti melakukan tindak pidana dapat dilindungi.

Hakim Anak dalam menjatuhkan putusannya terhadap kasus yang dilakukan oleh Anak, putusan hakim seperti halnya perkaraperkara diatas yaitu menjatuhkan pidana penjara dan denda dengan subsidair wajib latihan kerja, akan tetapi di dalam Diktum Putusan Hakim tidak mencantumkan lembaga mana yang harus melaksanakan wajib latihan kerja tersebut, sesuai dengan Pasal 32 Undang-Undang Nomor 11 Tahun 2012 tentang Sistem Peradilan Pidana Anak yang menyatakan bahwa "Apabila hakim memutuskan bahwa anak nakal wajib mengikuti 
pendidikan, pembinaan, dan latihan kerja, Hakim dalam keputusannya sekaligus menentukan lembaga tempat pendidikan, pembinaan dan latihan kerja tersebut dilaksanakan. ${ }^{7}$

Untuk pembinaan kesadaran hukum para narapidana anak, pelaksanaanya dilakukan melalui penyuluhan hukum yang bertujuan untuk mencapai kesadaran patuh hukum yang tinggi sehingga sebagai anggota masyarakat, mereka menyadari hak dan kewajibannya dalam rangka turut menegakkan hukum dan keadilan, perlindungan terhadap harkat dan martabat manusia, ketertiban, ketentraman, kepastian hukum dan terbentuknya perilaku warga negara indonesia yang taat kepada hukum, sehingga tumbuh sikap dan perilaku mereka yang tertib, disiplin serta mampu menggalang kesetiakawanan sosial. $^{8}$

Undang-Undang Sistem Peradilan Pidana Anak menitikberatkan adanya penguatan peran petugas kemasyarakatan. Petugas kemasyarakatan terdiri dari pembimbing kemasyarakatan, pekerja sosial profesional, dan tenaga kesejahteraan sosial. Pembimbing kemasyarakatan memiliki peran sentral dalam proses peradilan pidana, khusunya dalam penyusunan penelitian kemasyarakatan, pendampingan, dan pengawasan terhadap anak. penyidik diwajibkan untuk meminta pertimbangan dan saran dari pembimbing kemasyarakatan. Penelitian kemasyarakatan merupakan hal yang wajib untuk diperhatikan dalam setiap proses peradilan pidana anak. Dalam hal putusan pengadilan tidak mempertimbangkan penelitian kemasyarakatan, putusan tersebut menjadi batal demi hukum ( nietigheid van rechtswege ). Pekerja sosial profesional dan tenaga kesejahteraan sosial diantaranya bertugas untuk membuat laporan sosial sebagai informasi yang dibutuhkan penyidik dalam melakukan pemeriksaan terhadap anak korban dan atau saksi. Laporan sosial merupakan hal yang sangat penting, sehingga terhadap penyidik yang tidak meminta laporan sosial dapat dikenakan sanksi administratif. ${ }^{9}$

${ }^{7}$ Lina anggraini, wajib latihan kerja sebagai latihan alternatif sebagai sistem peradilan pidana anak (Studi Kasus Pada Lembaga Pembinaan Khusus Anak Pontianak), dikutip dalam jurnal. 13 February 2019. halaman 24.

${ }^{8}$ Wagiati Soetedjo. 2013. Hukum Pidana Anak. Bandung: PT Reflika Aditama, halaman 93.

${ }^{9}$ Lilik Mulyadi. 2014.Wajah Sistem Peradilan Pidana Anak Indonesia, Bandung : PT Alumni Bandung, halaman 38.
Dalam melakukan diversi, Pasal 9 ayat (1) huruf a Undang-Undang Nomor 11 Tahun 2012 Tentang Sistem Peradilan Pidana Anak ditentukan bahwa penyidik, penuntut umum, hakim harus mempertimbangkan Antara lain sebagai berikut;

a. Kategori tindak pidana

b. Umur Anak

c. Hasil penelitian kemasyarakatan dari Balai Pemasyarakatan(BAPAS)

d. Dukungan lingkungan keluarga dan masyarakat.

Pertimbangan tersebut harus diperhatikan oleh penyidik,penuntut umum, dan hakim dalam melaksanakan diversi. Disamping itu sebagaimana ketentuan dalam Pasal 9 ayat (2) Undang-Undang Nomor 11 Tahun 2012 bahwa kesepakatam diversi harus mendapat persetujuan korban atau keluarga anak korban serta kesedian anak dan keluarganya ,kecuali untuk:

a. Tindak pidana yang berupa pelanggaran.

b. Tindak pidana ringan.

c. Tindak pidana tanpa korban.

d. Nilai kerugian korban tidak lebih dari nilai upah minimum provinsi setempat.

Meskipun dalam melakukan diversi terhadap Anak seperti yang disebutkan dalam Pasal 9 ayat (2) Undang-Undang Nomor 11 Tahun 2012 tidak harus mendapatkan persetujuan korban atau keluarga Anak korban serta kesediaan Anak dan keluarganya. ${ }^{10}$

Hakim yang telah menjatuhkan putusan pidana demi perbaikan Anak, harus mengetahui keadaan orang tua, panti-panti atau lembaga pendidikan, sehingga anak betul-betul dapat menjadi baik dan tidak hilang kepercayaan baik kepada diri sendiri, kepada orang tuanya/wali/orang tua asuhnya. Petugas pembimbing kemasyarakatan harus membantu hakim mendapatkan keterangan-keterangan tersebut. Pembimbing kemasyarakatan perlu menunjukkan kesungguhan dalam mendengarkan yang diutarakan oleh klien. Pembimbing kemasyarakatan harus mengadakan hubungan yang baik dan sifatnya disengaja dalam mengadakan wawancara dengan klien, keluarga klien dan masyarakat di lingkungan klien. Pembimbing kemasyarakatan terlebih dahulu membuat suatu perjanjian agar diketahui bahwa pertemuan yang dilaksanakan adalah pertemuan yang disengaja. Ditentukan waktu dan tempat pertemuan. Pembimbing kemasyarakatan menciptakan hubungan mesra, sahingga klien merasa tenang dan dapat menceritakan segala

${ }^{10} \mathrm{R}$, Wiyono. 2015. Sistem Peradilan Pidana Anak Di Indonesia: Sinar Grafika, Jakarta, halaman 54. 
penderitaan bahkan masalah-masalah yang dihadapinya.

Balai pemasyarakatan merupakan salah satu unit pelaksana teknis dari direktorat jenderal pemasyarakatan, yang merupakan pelaksana sistem pemasyarakatan di luar lembaga pemasyarakatan. Salah satu tugasnya adalah membuat penelitian kemasyarakatan. Penelitian kemasyarakatan atau case studyini penting sebagai metode pendekatan dalam rangka pembinaan pelanggar hukum. Mengingat penting dan besarnya kegunaan pembuatan penelitian kemasyarakatan atau case study dalam membantu hakim untuk membuat suatu putusan yang tepat dan seadil-adilnya, dan untuk menentukan terapi pembinaan, isi laporan penelitian kemasyarakatan ini harus bisa memberikan gambaran tentang latar belakang kehidupan klien, baik dimasa lalu maupun setelah menjadi klien. Segala masalah yang terkandung di dalam kehidupannya serta lingkungan sosialnya dapat dicakup dalam isi laporan penelitian kemasyarakatan, meliputi:

a. Para pelanggar hukum anak-anak atau orang dewasa baik yang masih status tahanan maupun yang sudah mendapat putusan (vonis) hakim dan anak nakal yang oleh orang tuanya tidak sanggup lagi mengasuhnya dan memohon kepada hakim agar pengasuhnya diserahkan kepada negara, (anak sipil).

b. Terpidana yang diusulkan lepas dengan bersyarat.

Bimbingan kemasyarakatan merupakan pembinaan di luar lembaga pemasyarakatan. Bimbingan kemasyarakatan ditujukan kepada seseorang yang tidak dapat menjalankan fungsi sosialnya dalam masyarakat. Bimbingan kemasyarakatan adalah daya upaya yang dilakukan terhadap terpidana bersyarat anak dan anak didik dalam menghindari terjadinya pengulangan kembali pelanggaran hukum yang dilakukannya. Upaya tersebut mengikutsertakan unsur-unsur masyarakat untuk menyesuaikan kembali hubungan antara terpidana dengan keluarganya serta hubungan narapidana dengan masyarakat. ${ }^{11}$

Demikian juga masyarakat, seiring dengan kemajuan yang dialami masyarakat dalam berbagai bidang, bertambah juga peraturan-peraturan hukum. Penambahan peraturan hukum itu tidak dapat dicegah karena masyarakat berharap dengan bertambahnya peraturan tersebut, kehidupan dan keamanan

${ }^{11}$ Maidin Gultom. 2014.Perlindungan Hukum Terhadap Anak Dalam Sistem Peradilan Anak di Indonesia, Bandung, PT Reflika Aditama halaman 181 bertambah baik walaupun mungkin jumlah pelanggaran terhadap peraturan-peraturan itu bertambah. $^{12}$

\section{SIMPULAN dan SARAN}

Faktor dalam pelaksanaan hukuman pelatihan sebagai sistem pemidanaan bagi anak pengedar narkotika yaitu faktor intelegensia, faktor usia, faktor kedudukan anak dalam keluarga, faktor pendidikan dan sekolah, Sertadalam undang-undang narkotika itu tidak membedakan secara khusus antara pelaku tindak pidana narkotika, baik pelaku yang menyuruh lakukan, yang turut serta melakukan dan penganjur maupun pembantu dapat disebut sebagai pelaku tindak pidana. Keterlibatan anak dalam tindak pidana narkotika yang menjadi kurir narkotika merupakan suatu rangkaian permufaktan jahat dalam menjalankan peredaran narkotika secara ilegal, tetapi dalam kapasitas kategori anak yang menjadi kurir. Hal ini merupakan satu hal yang begitu memprihatinkan, di mana anak tersebut telah berhadapan dengan hukum dan tergolong telah melakukan tindak pidana narkotika. Tindakan hukum yang diberlakukan terhadap mereka harus lebih mengedepankan pembinaan dan pemulihan hakhak mereka, tanpa harus dikenai tindakan hukum yang berlebihan. Akan menjadi persoalan yang rumit dari sisi keadilan apabila konflik hukum terjadi bukan sekedar antara anak dengan negara atau masyarakat, akan tetapi konflik hukum itu terjadi juga dalam relasi antaranak yang samasama mempunyai hak mendapat perlindungan.

\section{SARAN}

Perlu adanya pengaturan khusus tentang undang-undang narkotika yang tidak membedakan secara khusus antara pelaku tindak pidana narkotika, baik yang menyuruh lakukan, yang turut serta melakukan dan penganjur maupun pembantu dapat disebut pelaku tindak pidana.

\section{DAFTAR PUSTAKA}

Fakultas hukum. 2018. Pedoman penulisan tugas akhir mahasiswa, Medan: Fakultas Hukum.

Leden Marpaung. 2009. Asas-Teori-Praktik Hukum Pidana. Jakarta. Sinar Grafika.

Lilik Mulyadi. 2014.Wajah Sistem Peradilan Pidana Anak Indonesia, Bandung : PT Alumni Bandung.

Maidin Gultom. 2014.Perlindungan Hukum Terhadap Anak Dalam Sistem Peradilan

\footnotetext{
${ }^{12}$ Leden Marpaung. 2009. Asas-Teori-
} Praktik Hukum Pidana. Jakarta. Sinar Grafika. Halaman 1. 
Anak di Indonesia, Bandung, PT Reflika Aditama.

Nursariani Simatupang dan Faisal. 2017. Kriminologi suatu pengantar. Medan: CV. Pustaka Prima

Soerjono Soekanto. 2014. Pengantar Penelitian Hukum. Jakarta: UI-PRESS

Wagiati Sutedjo. 2013. Hukum Pidana Anak. Bandung: PT Reflika Aditama.

Lina anggraini, wajib latihan kerja sebagai latihan alternatif sebagai sistem peradilan pidana anak (Studi Kasus Pada Lembaga Pembinaan Khusus Anak Pontianak), dikutip dalam jurnal “defenisi hukuman pelatihan bagi anak", melalui

,https://www.google.co.id/search?safe=s trict\&ei=gh9bXPS1O8XkvgSN0ZyICw $\& q=$ hukuman+pelatihan+bagi+anak\&o $\mathrm{q}=$ hukuman+pelatihan+bagi+anak\&gs_1 =psy-, diakses 7 february 2019 pukul $22.00 \mathrm{Wib}$.

"Serambinews.com, "memahami anak yg, berkonflik hukum" http://aceh.tribunnews.com/2017/01/26/ memahami-anak-yang-berkonflikhukum, diakses 2 januari 2019, pukul 09.00 WIB. 